same night, which varied with the lengths of path from about 0.5 to $0.7 \mathrm{sec}$, the velocity deduced would be between 39 and 27 miles per second, fairly agreeing with the real meteor-speed of the Perseids, which is 38 miles per second.

It would be interesting to learn if any observations were made elsewhere of a meteor seen at Tring at 9.32 P.M. on the I9th inst., descending from near the zenith at $3^{1} 7 \frac{1}{2}+37$, southwards to $320+\mathrm{I} 5$, which exceeded the fixed stars in brightness, and which was brilliant enough to attract the attentions of ordinary wayfarers there; so that with this observation of its path at Tring, its real course, and the position of its radiant-point in the northern sky might be determined. A. S. HERSCHEL.

Observatory House, Slough, Bucks, August 29.

\section{Do the Components of the Compound Colours in Nature follow a Law of Multiple Proportion?}

ON examining the data contained in Mr. Pillsbury's interesting and valuable résumé on colour measurements in the United States, by means of ordinates and abscissæe for the various colours on squared paper, it became at once evident from the parallelism of the diagonals which could be drawn that, although previously hidden, there was a numerical relation underlying them, and that probably the measurements would furnish an affirmative answer to the question printed at the head of this letter. Can it possibly be that those compound colours which occur with such profusion in nature are the result of simple colours being combined in definite multiple proportions? Can there be a law of multiple proportions here, similar to that which holds good in the domain of chemistry?

Let us see how far the data which Mr. Pillsbury gives support such a conclusion : they cannot from their paucity prove it. If we take all the foliage greens given, raise the percentage of black to Ioo in each case, and proportionately increase or decrease the yellows and greens, then the amount of yellow in each case divided by the amount of green in each case will give a ratio which, the black being equal, may be said to represent in figures the colour of the particular foliage. Now what do we find on examining the resulting ratios? They are all divisible into groups of multiples of $\mathbf{2}$, which may be represented as in the last column of the table by I-Y, $2-Y, 3-Y$. It will be noticed that while the figure in the second decimal place is not exactly a multiply of 2 , yet it tends very much in that direction.

\begin{tabular}{|c|c|c|c|c|c|c|}
\hline & \multirow{2}{*}{$\begin{array}{c}\text { Black. } \\
\text { I }\end{array}$} & \multirow{2}{*}{$\begin{array}{c}\text { Yellow. } \\
2.25\end{array}$} & Green. & $\begin{array}{c}\text { Yellow } \\
\quad \div\end{array}$ & Vellow. \\
\hline Hemlock-Sp & uce & & & IO'I & $.22)$ & $Y$ \\
\hline White Pine & $\ldots$ & , & 2.9 & $12 \cdot 8$ & $\cdot 22 j$ & $I-I$ \\
\hline Apple ... & $\ldots$ & ,", & $6 \cdot 25$ & 3.75 & 48 & \\
\hline Hornbeam & $\ldots$ & ,, & $6 \cdot 8$ & I 5.3 & $45 !$ & V \\
\hline Hickory & $\ldots$ & ", & $5 \cdot 3$ & I I ${ }^{\mathrm{I}}$ & $47 i$ & \\
\hline White Birch & $\ldots$ & ,, & $6 \cdot 8$ & $14 \cdot I$ & $48^{1}$ & \\
\hline White Oak & $\ldots$ &, & $9 \cdot 3$ & I 4.3 & .65 & $3-Y$ \\
\hline
\end{tabular}

Of course the conclusion reached cannot by any means be considered proved, as we do not know if the foliage greens were selected by Mr. Pillsbury purposely, or were merely the result of pure charice ; but it would seem amply to repay further investigation, and I should be pleased to hear that Mr. Pillsbury could undertake it, or, if he feels unable, but would furnish me with the necessary material, I would try and undertake it myself.

As much stress is laid upon the commercial utility of this system of colour measurement, might I suggest that in all cases the simple colour of which there was the largest quantity should be taken as measuring 10o? By this means there would always be one less number to recollect, write, or telegraph, than there are simple colours in the compound-no small factor when dealing with large quantities.

Churchfield, Edgbaston.

\section{Transformation of Moulds into Yeasts.}

THE experiments carried out in Dr. Jörgensen's laboratory in Copenhagen, on the morphological relations of moulds and yeasts, are of great interest, and have an important bearing upon the study of the Japanese method of saké-brewing, an investigation of which was made by the writer whilst in Japan, and the results of which were published by the National University of Japan in 1881 .

In this process a mould is caused to grow over the surface of steamed-rice until the grains are firmly matted together by the fibres of the mycelium, and this product (koji), mixed with fresh steamed-rice and water, is placed in mash-tuns and slightly warmed. After a short time active fermentation sets in, resulting in the preparation of a liquid (saké) containing as much as I 5 per cent. of alcohol. The question as to the origin of the ferment-cells was discussed in the memoir above referred to, and the conclusion was arrived at that there was no evidence to show that the mycelium underwent any change, but that the fermentcells were derived either from the air, or from the vats. or from spores which had attached themselves to the surface of the mycelium. Microscopic drawings were given illustrating the appearance of the mash at various periods during the fermentation, and in these the mycelium was seen to preserve its original form to the end of the process. The feature upon which most stress was laid by those who asserted that the mould was converted into the ferment, was the suddenness with which the fermentation showed itself, of which fact there could be no doubt; but it seemed to the writer that there was a very simple explanation of this. The fermentation appears immediately after the warming of the mash, which has already been exposed to the air in shallow vessels at a low temperature for several days before being collected into a single vat. It is also allowed to stand in this vat for several hours before heating, during which time probably all the dissolved oxygen has been used up by the ferment. By heating, the temperature is then raised to about $25^{\circ} \mathrm{C}$., a condition very favourable to the growth of yeast. Knowing how rapidly the yeast plant buds under such conditions, it does not seem necessary to invoke the transformation of the mycelium into ferment-cells to account for the sudden appearance of the fermentation.

The note (NATURE, August 22, p. 397) further says that Juhler found in his flasks in which the Japanese mould, Aspersillus oryze (called Eurotium oryzce in the writer's memoir), was cultivated a growth of typical alcohol-producing saccharomyces cells. If there were spores attached to the surface of the mycelium, it seems necessary to know in what manner they were destroyed before the introduction of the mould into the culture flasks. It would also be interesting to have more details of the size of these cells, to ascertain if they correspond exactly with those found in the native Japanese fermenting vats. The size of the full-grown cells measured by the writer were on the average $0.0082 \mathrm{~m} . \mathrm{m}$. in their longest diameter-that is, between the dimensions of ordinary beer-yeast and wine-yeast.

Cardiff, August 24.

R. W. Atrinson.

IN reply to Mr. Atkinson's inquiries, we would refer him to Juhler's original communication on his experiments with Aspergillus oryze, to be found in part ii. of the Centralblatt für Bakteriologie, Nos. I and 9, 1895.

August 29.

The Writer of THE Note.

\section{Mr. Seebohm on Middendorff's Credibility.}

Mr. Sefiohm writes (antea p. 385$)$ : "There is no reason to believe that Middendorff ever found the eggs of the little stint. The eggs which he records as being those of Tringa minuta were probably those of T'ringa ruficollis and possibly those of Tringa subminuta." To me these statements seem made in oblivion of the facts, and as some years ago I exhibited in London (Proc. Zool. Soc., 186r, p. 398) one of the specimens on which doubt is thus thrown, I beg leave to show that there is no reason for believing that distinguished explorer to have been mistaken. The only eggs he records (Sib. Reise, II. ii. p. 22I) are four, the parent of which he caught under his game bag. No other nest is mentioned, and this one was found on July I, I 843 , in the Taimyr peninsula, which is admitterlly as well within the range of $T$. minuta, as it is outside of that recorded for $T$. ruficollis (cf. Palmén, Vega-Exped. Vetenskapl. Jakttagelser, v. tab. 4). Though not recognising these two birds as good species, Von. Middendorff had carefully noticed (tom. cit. p. 222) the difference between examples obtained in the far East (Ochotsk) and in the high North (Taimyr), expressly stating that the latter agreed with Naumann's figure which undoubtedly represents $T$. minuta in summer plumage. As to $T$. subminuta, I am not aware of any evidence of its occurrence in the Taimyr, and by conjecture only can it be ascribed to that district; but the supposition that a single nest can have belonged to both $T$. ruficollis "and possibly" T. subminuta, is a masterpiece of conjecture wholly above my power of comprehension.

Magdalene College, Cambridge, August 23.
Alfred Newton.

No. 1349 , vol.. 52] 